\title{
LIST OF IMAGES
}

1-The Crystal Palace (North Transept), the Great Exhibition in London, design by Joseph Paxton (1851). Tallis's History and Description of the Crystal Palace, and the Exhibition of the World's Industry in 1851, vol. 3 (London, 1852) 41

2-The exhibition pavilion for the 1862 World's Fair in London, design by Captain Francis Fowke. Illustrated London News, 24 May 186245

3-Gravestone of Vladimir Stasov, sculptor I. Ia. Gintsburg, architect I. P. Ropet (1908). The Necropolis of Artists, Alexander Nevsky Monastery in St. Petersburg 47

4-Ignaty Sazikov's silver centerpiece with the Grand Duke Dmitry Donskoy. Tallis's History and Description of the Crystal Palace, and the Exhibition of the World's Industry in 1851, vol. 2 (London, 1852) 60

5-Nikolai Ge, The Last Supper (1863) 105

6-Vasily Pukirev, The Unequal Marriage (1862) 107

7-The Millennium of Russia monument in Novgorod, sculptor M. O. Mikeshin (1862) 123

8-Sculptural group representing writers, artists, and musicians, The Millennium of Russia monument, fragment (1862). Photo by Dar Veter 127

9-Karl Briullov, The Last Day of Pompeii (1830-33) 139

10--Pavel Fedotov, The Major's Courtship (1848) 151

11 -Adrian Volkov, The Interrupted Betrothal (1860) 153

12 -Ilya Repin, Barge Haulers on the Volga (1870-73) 167

13-Ilya Repin, Portrait of Pavel Mikhailovich Tretiakov, Founder of the Gallery (1883) 174 
14-Russian Pavilion at the 1878 International Exhibition in Paris, design by I. Ropet 193

15-The Historical Museum in Moscow, architect V. O. Shervud (1875-83) 214

16-Abramtsevo workshop, design by V. Gartman (1872) 230

17-Teremok in Flenovo near Talashkino, design by S. Maliutin (1900s). Sergei Makovskii, Talachkino: Lart décoratif des ateliers de la princesse Ténichef (St. Pétersbourg: Édition “Sodrougestvo," 1906) 238

18-Pavel Shcherbov, The Idyll. Shut, no. 13 (1899) 241

19-Pavel Shcherbov, Salzburg. Shut, no. 6 (1898) 243

20-Viktor Vasnetsov, Tsar Berendey's Palace. Set design for RimskyKorsakov's opera Snow Maiden (1885) 249

21 -Viktor Vasnetsov, The Snow Maiden (1899) 252

22--The Kustar Pavilion at the Exposition Universelle in Paris, design by K. Korovin and A. Golovin (1900). Mir iskusstva, no. 21/22 (1900) 259

23-The interior of the Kustar Pavilion at the Exposition Universelle in Paris (1900), detail. Mir iskusstva, no. 21/22 (1900) 260

24-Pavel Shcherbov, Vavila Barabanov and Nikola Kritichenko Having an Intimate Conversation about Aesthetics. Shut, no. 10 (1898) 269

25-Pavel Shcherbov, The Bazaar of the 20th Century (1908). Courtesy of The State Tretiakov Gallery, Moscow 275

26-Cover page for The Cornfield journal (1898) 277 